\title{
RECENT ADVANCES IN EUROPEAN ACCOUNTING: THE CASE OF ITALY
}

\author{
Annalisa Baldissera ${ }^{259}$
}

https://doi.org/10.31410/itema.2018.681

\begin{abstract}
Following the implementation of Directive 2013/34/EU (hereafter the Directive), significant innovations have recently been introduced in the European Union countries to prepare the financial statements of non-listed companies. In Italy, the aforementioned Directive was implemented with Legislative Decree no. 139 of 18/8/2015 and applies starting from the financial statements for the financial year 2016. Two years have passed since the first application and it is now possible to analyze the effects of this reform in the Italian context. The purpose of this study is to verify whether the aforementioned reform has brought real benefits, and especially if it has improved the information that can be obtained from the financial statement for decision-making by managers and stakeholders. Through this contribution, the reader can learn: a) the main rules for preparing the financial statements of Italian non-listed companies; b) improve reading and interpreting the financial statements of Italian companies. The method used is inductive-deductive and is based: i) on the analysis of the recent regulatory framework; ii) on the empirical survey, conducted on the financial statements of some nonlisted Italian companies, for the four-year period 2014-2017; iii) on the quantitative costbenefit analysis of the reformed rules. The findings of the research are the sequent. 1) The statement of cash flows, introduced in Italy for the first time by the Directive, provides summary information useful to the reader of the financial statements, but less useful to managers, for whom historical data are not sufficient, because they also need information to plan the future.

2) The evaluation criteria have been made more complex, but in the face of the increased technical and applicative difficulties, the benefit in terms of utility for managers and readers of the financial statement is not commensurate with the effort and resources required. 3) The quantitative survey led to a cost-benefit indicator generally not less than $1[(C / B) \geq 1]$.
\end{abstract}

Keywords: Italian Accounting, Financial Statement, non-listed companies.

\section{INTRODUCTION}

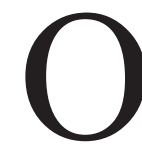
n 26 June 2013, the European Parliament and the Council of the European Union adopted Directive 2013/34 concerning the annual and consolidated financial statements of certain types of companies.

As a result of the adoption, the previous Council Directives 78/660/EEC and 83/349/EEC, concerning the regulation of the financial statements and consolidated financial statements of the joint stock companies and other subjects identified by law, have been repealed.

The implementation of the Directive in Italy has made significant changes in the preparation of the financial statements of non-listed companies, in force since 2016 [1] - [2] - [3].

\footnotetext{
${ }^{259}$ University of Brescia, Department of Law, Via San Faustino, 41, 25122, Brescia, Italy
} 
These innovations are part of the process of progressive alignment of the principles in force in the civil law countries with the IAS/IFRS International Accounting Standards [4] - [5].

It is necessary, however, not to forget that the structure and accounting tradition of most of the countries of Continental Europe are based on two central rules: a) the criterion of historical $\operatorname{cost}$; b) the protection of social creditors; while the IAS/IFRS accounting principles are based on rules that tend to be opposed, namely: a) the criterion of fair value; b) the information in favor of investors (current and potential) [6] - [7].

With particular reference to Italy, the reform entailed: 1) the adoption of mathematical-financial techniques and procedures, generally not used by non-listed companies; 2) the support of additional administrative burdens, connected to the most complex rules of drafting of the financial statement.

The purpose of this contribution is to critically consider the innovations mentioned above in order to understand whether they -given the resulting efforts and costs- have effectively contributed to improving financial reporting, both towards managers and stakeholders.

\section{METHODOLOGY}

The main methods used for this analysis are as follows. 1) Theoretical investigation, which consists of a comparative analysis of the norms prior to the implementation of the Directive with the rules applicable from 2016. 2) Empirical survey, which consists in the analysis of the financial statements of three Italian non-listed companies, belonging to a group of companies, for the period 2014-2017.3) Quantitative investigation, which was carried out through a costbenefit analysis (CBA) [8].

\section{COMPARISON BETWEEN LEGAL RULES}

Among the main innovations produced by the Directive we consider those summarized in Table 1 , in which the current legislation is compared with the repealed legislation.

Table 1: Reference legislation

\begin{tabular}{|c|c|c|}
\hline$A R G U M E N T$ & CURRENT LEGISLATION & REPEALED LEGISLATION \\
\hline Cash flow statement & Required (articles 2423 and 2425 ter c.c.) & Optional \\
\hline Valuation of securities & Amortized cost (art. 2426 c.c.) & $\begin{array}{l}\text { Subscription cost and write-downs in } \\
\text { the event of permanent losses (art. } 2426 \\
\text { c.c.) }\end{array}$ \\
\hline Valuation of receivables and payables & Discounted amortized cost (art. 2426 c.c.) & $\begin{array}{l}\text { Realizable value (receivables), nominal } \\
\text { value (payables) (art. } 2426 \text { c.c.) }\end{array}$ \\
\hline Valuation of derivative financial instruments & Fair value (articles 2426 and 2427 bis c.c.) & $\begin{array}{l}\text { Not to account; to be described in the } \\
\text { explanatory note (art. } 2427 \text { bis c. c.) }\end{array}$ \\
\hline Extraordinary area of the income statement & Abolished & Present (art. 2425 c.c.) \\
\hline Memorandum accounts & $\begin{array}{l}\text { To be indicated in the explanatory note (art. } \\
2427 \text { c.c.) }\end{array}$ & $\begin{array}{l}\text { To be indicated at the foot of the } \\
\text { balance sheet (art. } 2424 \text { c.c.) }\end{array}$ \\
\hline Recording of own shares & $\begin{array}{l}\text { In a negative reserve of net equity (articles } \\
2357 \text { ter and } 2424 \text { c.c.) }\end{array}$ & $\begin{array}{l}\text { Among balance sheet assets (articles } \\
2357 \text { ter and } 2424 \text { c.c.) }\end{array}$ \\
\hline Recording of research and advertising costs & Only in the income statement & $\begin{array}{l}\text { Possibility of capitalizing in the balance } \\
\text { sheet }\end{array}$ \\
\hline Detail of relationships with sister companies & $\begin{array}{l}\text { To be recorded both in the balance sheet and in } \\
\text { the income statement (articles } 2424 \text { and } 2425 \\
\text { c.c.) }\end{array}$ & 然 \\
\hline Depreciation of goodwill & According to its useful life (art. 2426 c.c.) & Within five years (art. 2426 c.c.) \\
\hline
\end{tabular}




\section{THE EMPIRICAL SURVEY}

The empirical survey was conducted by assessing the impact of the new rules for preparing the financial statements on three Italian non-listed companies belonging to the same group, within which the parent company draws up the financial statements in ordinary form and the two subsidiaries prepare the financial statements in abbreviated form. The period of analysis (20142017) was chosen in such a way as to include both financial statements prepared according to the repealed rules, and financial statements prepared in accordance with the provisions in force, as amended by the Directive.

The financial statement data have been re-aggregated so as to highlight in separate lines the main information added by the Directive and those deleted (see Tables 2, 3 and 4).

Table 2: Company A (holding)-Financial statements in ordinary form

\begin{tabular}{l|r|r|r|r}
\hline ITEM & $\mathbf{2 0 1 4}$ & $\mathbf{2 0 1 5}$ & $\mathbf{2 0 1 6}$ & $\mathbf{2 0 1 7}$ \\
\hline Assets towards sister companies & Absent item & Absent item & 166.864 & 176.702 \\
Assets towards others & 105.767 .365 & 104.720 .657 & 104.875 .967 & 106.106 .417 \\
Active derivative financial instruments & Absent item & Absent item & 0 & 0 \\
Liabilites towards sister companies & Absent item & Absent item & 1.257 .401 & 807.788 \\
Liabilites towards others & 24.170 .040 & 17.505 .325 & 10.494 .184 & 11.885 .230 \\
Passive derivative financial instruments & Absent item & Absent item & 0 & 0 \\
Net equity & 81.597 .325 & 87.215 .332 & 93.291 .246 & 93.590 .101 \\
Memorandum accounts & 529.166 & 533.166 & Deleted item & Deleted item \\
Production value & 68.534 .098 & 53.001 .972 & 49.543 .208 & 49.346 .573 \\
Production costs & 66.422 .890 & 53.609 .997 & 50.181 .722 & 49.718 .710 \\
Operating result & 2.111 .208 & $(608.025)$ & $(638.514)$ & $(372.137)$ \\
Result of the financial area & 1.212 .882 & 1.014 .410 & 914.428 & 738.209 \\
Results of operations in derivative financial instruments and & Absent item & Absent item & 0 & 0 \\
with sister companies & 100.387 & 87.762 & Deleted item & Deleted item \\
Result of extraordinary area & 2.788 .497 & 176.140 & 0 & 67.217 \\
Income taxes & 635.980 & 318.007 & 275.914 & 298.855 \\
Net income (loss) & &
\end{tabular}

Source: Register of Companies of Brescia - Italy

Table 3: Company B (subsidiary) - Financial statements in abbreviated form

\begin{tabular}{l|r|r|r|r}
\hline ITEM & $\mathbf{2 0 1 4}$ & $\mathbf{2 0 1 5}$ & $\mathbf{2 0 1 6}$ & $\mathbf{2 0 1 7}$ \\
\hline Assets towards sister companies & Absent item & Absent item & Absent item & Absent item \\
Assets towards others & 3.145 .148 & 3.139 .755 & 3.901 .004 & 4.392 .534 \\
Active derivative financial instruments & Absent item & Absent item & Absent item & Absent item \\
Liabilites towards sister companies & Absent item & Absent item & Absent item & Absent item \\
Liabilites towards others & 876.655 & 682.517 & 942.509 & 856.983 \\
Passive derivative financial instruments & Absent item & Absent item & Absent item & Absent item \\
Net equity & 2.268 .493 & 2.457 .238 & 2.958 .495 & 3.535 .551 \\
Memorandum accounts & 1.430 & 1.430 & Deleted item & Deleted item \\
Production value & 3.181 .623 & 2.476 .796 & 3.404 .560 & 3.579 .951 \\
Production costs & 2.813 .740 & 2.217 .871 & 2.683 .955 & 2.787 .266 \\
Operating result & 367.883 & 258.925 & 720.605 & 792.685 \\
Result of the financial area & 7.073 & 7.925 & 10.793 & 11.859 \\
Results of operations in derivative financial instruments and with & Absent item & Absent item & 0 & 0 \\
sister companies & 4.027 & $(43)$ & Deleted item & Deleted item \\
Result of extraordinary area & 131.000 & 78.062 & 230.141 & 227.488 \\
Income taxes & 247.983 & 188.745 & 501.257 & 577.056 \\
Net income (loss) & & &
\end{tabular}

Source: Register of Companies of Padova - Italy

Table 4: Company C (sister of the holding) - Financial statements in abbreviated form

\begin{tabular}{|c|c|c|c|c|}
\hline ITEM & 2014 & 2015 & 2016 & 2017 \\
\hline Assets towards sister companies & Absent item & Absent item & Absent item & Absent item \\
\hline Assets towards others & 6.815 .363 & 7.346 .193 & 7.876 .923 & 7.960 .491 \\
\hline Active derivative financial instruments & Absent item & Absent item & Absent item & Absent item \\
\hline Liabilites towards sister companies & Absent item & Absent item & Absent item & Absent item \\
\hline Liabilites towards others & 2.468 .607 & 1.681 .125 & 854.939 & 848.901 \\
\hline Passive derivative financial instruments & Absent item & Absent item & Absent item & Absent item \\
\hline Net equity & 4.346 .756 & 5.665 .068 & 7.021 .984 & 7.111 .590 \\
\hline Memorandum accounts & 0 & 0 & Deleted item & $\begin{array}{r}\text { Deleted } \\
\text { item }\end{array}$ \\
\hline
\end{tabular}




\begin{tabular}{|c|c|c|c|c|}
\hline Production value & 6.457 .254 & 5.134 .621 & 4.862 .774 & 4.156 .462 \\
\hline Production costs & 5.896 .063 & 4.809 .453 & 3.981 .892 & 4.155 .870 \\
\hline Operating result & 561.191 & 325.168 & 880.882 & 592 \\
\hline Result of the financial area & 38.472 & 52.290 & 74.323 & 114.783 \\
\hline $\begin{array}{l}\text { Results of operations in derivative financial instruments and } \\
\text { with sister companies }\end{array}$ & Absent item & Absent item & 0 & 0 \\
\hline Result of extraordinary area & 3.126 & $(123)$ & Deleted item & $\begin{array}{l}\text { Deleted } \\
\text { item }\end{array}$ \\
\hline Income taxes & 389.941 & 59.023 & 298.290 & 25.769 \\
\hline Net income (loss) & 212.848 & 318.312 & 656.915 & 89.606 \\
\hline
\end{tabular}

Source: Register of Companies of Brescia - Italy

Finally, in Table 5, we present a summary of the cash flow statement of the holding A alone, for the years 2016 and 2017, considering that before the Directive the document was not mandatory and also considering that companies $\mathrm{B}$ and $\mathrm{C}$ are still exempt from the drafting of it, as they present the financial statement in abbreviated form.

Table 5: Company A (holding) - Synthetic Statement of Cash Flows

\begin{tabular}{l|r|r}
\hline ITEM & 2017 & 2016 \\
\hline A) Cash flows from operating activities & & \\
Profit (loss) for the year & 298.855 & 275.914 \\
Income taxes & 67.217 & 0 \\
Active interests & $(706.424)$ & $(921.500)$ \\
(Dividends) & $(20.313)$ & $(40.391)$ \\
(Gains)/Losses deriving from the sale of assets & $(4.082)$ & $(7.813)$ \\
1) Profit (loss) for the year before income taxes, interest, dividends and gains/losses on disposal & $\mathbf{( 3 6 4 . 7 4 7 )}$ & $\mathbf{( 6 9 3 . 7 9 0 )}$ \\
Adjustments for non-monetary items that did not affect the net working capital & 1.380 .157 & 1.339 .244 \\
2) Financial flow before changes in net working capital & $\mathbf{1 . 0 1 5 . 4 1 0}$ & $\mathbf{6 4 5 . 4 5 4}$ \\
Changes in net working capital & $(1.882 .359)$ & $(59.451)$ \\
3) Financial flow after changes in net working capital & $\mathbf{( 8 6 6 . 9 4 9 )}$ & $\mathbf{5 8 6 . 0 0 3}$ \\
Other adjustments & 42.197 & $(863.744)$ \\
Cash flow from operating activities (A) & $\mathbf{( 8 2 4 . 7 5 2 )}$ & $\mathbf{( 2 7 7 . 7 4 1 )}$ \\
B) Financial flows deriving from investment activity & $\mathbf{( 4 . 7 4 3 . 0 9 5 )}$ & $\mathbf{( 9 4 9 . 8 4 4 )}$ \\
C) Financial flows deriving from financing activities & $\mathbf{0}$ & $\mathbf{0}$ \\
Increase (decrease) in liquid assets (A \pm B \pm C) & $\mathbf{( 5 . 5 6 7 . 8 4 7 )}$ & $\mathbf{( 1 . 2 2 7 . 5 8 5 )}$ \\
Liquidity at the beginning of the financial year & 40.775 .134 & 42.002 .719 \\
Liquidity at the end of the financial year & $\mathbf{3 5 . 2 0 7 . 2 8 7}$ & $\mathbf{4 0 . 7 7 5 . 1 3 4}$ \\
\hline
\end{tabular}

Source: Register of Companies of Brescia - Italy

\section{THE COST-BENEFIT ANALYSIS}

It is necessary to consider that the technical complexities related to the new evaluation criteria do not emerge from the financial statements; therefore, we propose here a cost-benefit analysis [9] - [10] - [11], based on the information provided by management and by the administrative offices of companies A, B and C.

To this end, the analysis was conducted jointly for the management [12] and for the stakeholders [13] - [14], taking into account that the costs essentially fall on the first, while the benefits may be related to both.

Moreover, given the difficulty of quantifying the variables in monetary terms, reference was made to a physical parameter, expressed in the number of additional hours used to prepare the financial statements and in the number of hours saved thanks to the information provided by the financial statements.

On this basis, the costs are expressed as:

$\mathrm{H}_{\mathrm{e}}=$ additional hours employed,

while the benefits are expressed as:

$\mathrm{H}_{\mathrm{s}}=$ hours saved. 
In relation to management, the greater use of time was absorbed by the activities indicated in Table 6.

In relation to the benefits, they were considered, for the management, in terms of hours saved for taking decisions, while, with reference to the stakeholders, we considered the hours saved in the formulation of an economic opinion on the company, assuming a medium level of knowledge of accounting matters.

Table 6: Hours employed and saved

\begin{tabular}{l|l|l}
\hline ACTIVITY $(*)$ & $\boldsymbol{H}_{\boldsymbol{e}}$ & $\boldsymbol{H}_{\boldsymbol{s}}$ \\
\hline Amortized cost of fixed securities & 20 & 2 \\
Amortized cost of working capital securities & 20 & 2 \\
Amortized cost of receivables & 1 & 2 \\
Amortized cost of payables & 0 & 0 \\
Fair value for derivative financial instruments & 5 & 0 \\
Preparation of the cash flow statement & 10 & 10 \\
TOTAL & $\mathbf{5 6}$ & $\mathbf{1 6}$ \\
\hline
\end{tabular}

$\left(^{*}\right)$ The activity must be understood also as verification of the existence of the conditions for application of the relative criterion.

Therefore the $\mathrm{C} / \mathrm{B}$ indicator has the following value:

$\mathrm{C} / \mathrm{B}=56 / 16=3.5$.

\section{CRITICAL CONSIDERATIONS}

The cost-benefit analysis requires considering an additional profile linked to the level of knowledge that -after the reform- must possess the external reader [15] - [16] of the financial statement for the correct interpretation of accounting information.

In fact, in the cost-benefit analysis proposed above, an adequate level of preparation of the interpreter was purposely assumed, such as to prevent the calculation of the hours saved could be penalized by insufficient competence in the matter.

However, it is necessary to take into account the fact that, prior to Legislative Decree 139/2015, the reading of the financial statements required a lower level of knowledge of accounting matters; the financial statement, in fact, was less complex [17] and technically understandable by a greater number of subjects.

In this regard, we recall that one of the primary objectives pursued by the Directive consists precisely in improving the financial reporting [18], in favor of shareholders and third parties.

But, to achieve this goal, we think that it is necessary not only to make the information more sophisticated, but also to ensure that the audience of the recipients able to read them widens as much as possible, rather than shrinking.

On the contrary, I believe that this has not happened because the reading of the new financial statement implies the knowledge of complex evaluation techniques (also of a financial type) which, in many respects, are less intelligible than the previous historical cost.

I refer, in particular, to the following evaluation criteria, which, not by chance, are the same ones that the empirical survey has shown to be more expensive, in terms of time:

1) the amortized cost criterion for the valuation of the securities [19];

2) the amortized cost criterion for the valuation of receivables and payables [20]; 
3) the fair value criterion for the valuation of derivative financial instruments [21].

The application sub 1) of the amortized cost criterion for the valuation of the securities involves numerous operations, among which I mainly remember:

a) the verification of the existence of the conditions for the application of the criterion (for example, the presence of measurable periodic flows);

b) the reconstruction of future flows associated with the security;

c) the calculation of the IRR (Internal Rate of Return) [22];

d) the formulation of the amortization plan of the differential emerging from the comparison between nominal rate of return and effective rate of return.

Similarly, the application sub 2) of the amortized cost criterion for the valuation of receivables and payables requires the execution of a series of operations, among which I remember:

a) the determination of the effective interest rate;

b) the formulation of the amortization plan, using the effective interest rate, in place of the nominal one;

c) the calculation of the amortized cost;

d) the application of discounting, in the event that the nominal interest rate diverges appreciably from the market interest rate.

Finally, the application sub 3) of the fair value criterion for the valuation of derivative financial instruments is even more complex than the two previous ones.

In particular, the evaluation process is carried out through the following steps, alternative or copresent:

a) application of market prices, for listed derivative financial instruments;

b) application of the market prices of similar financial instruments, in the absence of listing of the derivative financial instrument to be valued;

c) application of generally accepted valuation techniques, in the absence of quotations both of the derivative financial instrument to be valued, and of similar financial instruments;

d) non-application of the fair value criterion where it does not lead to a reliable result.

Therefore, the reader can consciously judge the values of the financial statements only through the knowledge of the variables and of the procedures that led to the accounting results. In other words, it is necessary that the stakeholders know at least: what the IRR is; what is the amortization plan of the differentials between the rates; what is a derivative financial instrument; what are the generally accepted fair value calculation techniques, etc.

I therefore believe that the audience of those who actually have a substantial knowledge of the elements considered above is certainly narrower than that of those who know the meaning of the simplest and least conjectured historical cost [23] - [24].

\section{CONCLUSIONS}

The examination of the financial statements of companies $\mathrm{A}, \mathrm{B}$ and $\mathrm{C}$ shows how the information provided by the accounting schedules useful for the decisions of managers and stakeholders has not obtained a significant improvement, for the following reasons.

First of all, the main indicators of income and financial performance (ROE, ROI, ROS, financial independence index, etc.) [25] - [26] - [27] remained substantially unchanged, as no further 
significant indicators could be deduced from the reformed financial statement compared to those that can be derived before the reform.

Secondly, a sort of compensation between added information and suppressed information has taken place: on the one hand, in fact, and only for ordinary financial statements, the changes made by the Directive make it possible to assess the extent of relationships between sister companies and that of transactions in financial derivative instruments; on the other hand, however, they have provoked the loss of information relating to the memorandum accounts [28] - [29] and to extraordinary income items [30] - [31], also for the companies that prepare the financial statements in abbreviated form. For both this information, the reader of the financial statements must also read the explanatory note [32].

Thirdly, it is necessary to remember that the reform introduced the obligation to draw up the cash flow statement, which, even before the Directive, was strongly recommended by the National Accounting Standards [33]. In effect, this document offers stakeholders significant information on the contribution of the various areas of management to increases or decreases in cash and cash equivalents during the year [34], while it presents a different utility for managers who, for decision-making purposes, can certainly draw important data from past management, but must additionally formulate appropriate hypotheses on future management [35] - [36] and on the cash flows that it will be able to produce [37] - [38].

Finally, in relation to the cost-benefit analysis, it is necessary to consider, first of all, the limits of the survey, which is particularly affected by: a) the subjectivity (technical capacity, theoretical and practical preparation) of the editor and the reader of the financial statement; $b$ ) the limited size of the chosen sample, which would require a more extensive empirical analysis.

However, the result obtained is far superior to unity (3.5), showing -although in an indicative and symptomatic manner- as the innovations introduced by the Directive have not led to an effective improvement of the financial statement disclosure, in spite of a significant increase in the application complexity and in the technical training required by the preparation of the accounting and extra-accounting tables.

\section{REFERENCES}

[1] Quagli, A. (2017), Bilancio di esercizio e principi contabili, Giappichelli, Torino.

[2] Canziani, A. (ed.) (2017), Il bilancio di esercizio delle imprese, Wolters Kluwer, Padova.

[3] Superti Furga, F. (2017), Il bilancio di esercizio italiano secondo la normativa europea, Giuffrè, Milano.

[4] Epstein, B. J., Jermacovicz E. K. (2010), Interpretation and Application of International Financial Reporting Standards, Wiley, Hoboken.

[5] Van Greuning, H., Scott, D., Terblanche, S. (2011), International Financial Reporting Standards. A Practical Guide, The World Bank, Washington D. C.

[6] Sale, T. J. (ed.) (2005), Advances in International Accounting. Volume 18, Elsevier, Amsterdam.

[7] Bensadon, D., Praquin, N. (eds.) (2016), Essays in Honor of Professor Jacques Richard. IFRS in a Global World. International and Critical Perspectives on Accounting, Springer, Cham.

[8] Sorrentino, M. (2017), La regolamentazione contabile: teorie, costi e benefici, FrancoAngeli, Milano.

[9] Robinson, R. (1993), Cost-Benefit Analysis, BMJ, 307:924. 
[10] Mishan, E. J., Quah, E. (2007), Cost-Benefit Analysis, Routledge, London.

[11] Boardman, A. E., Greenberg, D. H., Vining, A. R., Weimer, D. L. (2018), Cost-Benefit Analysis. Concepts and Practice, Cambridge University Press, Cambridge.

[12] Koen, M., Oberholster, J. (1999), Analysis and Interpretation of Financial Statements, Juta, Kenwyn.

[13] Lee, T. A. (2006), Financial Reporting and Corporate Governance, Wiley, Chichester.

[14] Alexander, D., Britton, A., Jorissen, A. (2007), International Financial Reporting and Analysis, Thomson, London.

[15] Gibson, C. H. (2013), Financial Reporting and Analysis. Using Financial Accounting Information, Cengage Learning, Mason.

[16] Warren, C., Reeve, J. M., Duchac, J. (2018), Financial Accounting, Cengage Learning, Boston.

[17] Garesio, G. (2016), Il recepimento della Direttiva 2013/34/UE: il progressivo allineamento delle disposizioni contabili racchiuse nel codice civile ai principi IAS/IFRS, Orizzonti del diritto commerciale, No 1, pp. 1-31.

[18] Onesti, T., Romano, M., Taliento, M. (2016), Il bilancio di esercizio nelle imprese. Dal quadro concettuale di riferimento alle nuove regole contabili nazionali e internazionali, Giappichelli, Torino.

[19] Sòstero, U., Santesso, E. (2018), I principi contabili per il bilancio d'esercizio. Analisi e interpretazione delle norme civilistiche, Egea, Milano.

[20] Mirza, A. A., Orrel, M., Holt, G. J. (2008), IFRS. Practical Implementation. Guide and Workbook, Wiley, Hoboken.

[21] Zack, G. M. (2009), Fair Value Accounting Fraud. New Global Risks and Detection Techniques, Wiley, Hoboken.

[22] Gallagher, T. J., Andrew, J. D. (2007), Financial Management. Principles and Practice, Freeload Press, USA.

[23] Schwartz, R. J., Smith, C. W. (eds.) (1997), Derivatives Handbook. Risk Management and Control, Wiley, New York.

[24] Greenberg, M. D., Helland, E., Clancy, N., Dertouzos, J. (2013), Fair Value Accounting, Historical Cost Accounting and Systemic Risk. Policy Issues and Options for Strengthening Valuation and Reducing Risk, Rand Corporation, Santa Monica.

[25] Caramiello, C., Di Lazzaro, F., Fiori, G. (2003), Indici di bilancio. Strumenti per l'analisi della gestione aziendale, Giuffrè, Milano.

[26] Teodori, C. (2017), Analisi di bilancio. Lettura e interpretazione, Giappichelli, Torino.

[27] Mella, P., Navaroni, M. (2012), Analisi di bilancio. Indici e flussi. Apprezzamenti e simulazioni, Maggioli, Santarcangelo di Romagna.

[28] Marchi, L. (ed.) (2013), Contabilità d'impresa e valori di bilancio, Giappichelli, Torino.

[29] Pavan, A. (2008), L'amministrazione economica delle aziende, Giuffrè, Milano.

[30] Zappa, G. (1950), Il reddito di impresa. Scritture doppie, conti e bilanci di aziende commerciali, Giuffrè, Milano.

[31] D'Ippolito, T. (1958), La contabilità in partita doppia a sistema unico e duplice ed il bilancio d'esercizio, Abbaco, Palermo.

[32] Cordazzo, M., Bianchi, S. (eds.) (2018), Il nuovo bilancio dopo l'applicazione del D. Lgs. 139/2015. Implicazioni teoriche ed evidenze empiriche, FrancoAngeli, Milano.

[33] OIC 12, 30 maggio 2005.

[34] Klammer, T. (2018), Statement of Cash Flows. Preparation, Presentation and Use, Wiley, Newark.

[35] Jury, T. (2012), Cash Flow Analysis and Forecasting. The definitive Guide to Understanding, Wiley, Hoboken. 
[36] De Gobbis, F. (1934), Ragioneria Generale. Corso teorico-pratico, Dante Alighieri, Milano.

[37] Caratozzolo, M. (2006), Il bilancio d'esercizio, Giuffrè, Milano.

[38] Johal, P., Vickerstaff, B. (2014), Financial Accounting, Routledge, London-New York. 